\title{
Bioactivity of Licaria puchury-major Essential Oil Against Aedes aegypti, Tetranychus urticae and Cerataphis lataniae
}

\author{
Sidney G. Azevedo $\odot^{1}$, Josiana M. Mar $\odot^{1,2}$, Laiane S. da Silva $\odot^{1}$, Leandro \\ P. França $\odot^{1}$, Marcos B. Machado $\odot^{2}$, Wanderli P. Tadei $\odot^{3}$, Jaqueline de A. \\ Bezerra $\odot^{2,4}$, Amanda L. dos Santos $\odot^{5}$ and Edgar A. Sanches $\odot^{1^{*}}$ \\ ${ }^{1}$ Laboratório de Polímeros Nanoestruturados (NANOPOL), UFAM, Manaus/AM, Brasil \\ ${ }^{2}$ Núcleo de Estudos Químicos de Micromoléculas da Amazônia (NEQUIMA), UFAM, Manaus/AM, Brasil \\ ${ }^{3}$ Laboratório de Malária e Dengue - Instituto Nacional de Pesquisa da Amazônia (INPA), Manaus/AM, \\ Brasil \\ ${ }^{4}$ Instituto Federal de Educação Ciência e Tecnologia do Amazonas (IFAM), Manaus/AM, Brasil \\ ${ }^{5}$ Nanomed Inovação em Nanotecnologia, São Carlos/SP, Brasil
}

(Received May 22, 2017; Revised September 29, 2017; Accepted October 01, 2017)

\begin{abstract}
The present study was carried out to evaluate an alternative controlling agent for greenhouse pests and the yellow fever mosquito larvae. The potential bioactivity of Licaria puchury-major (Mart.) Kosterm. ("puxuri") was evaluated here against three most common pests in tropical and subtropical countries: Aedes aegypti Linn. Larvae, Tetranychus urticae Koch. mites and Cerataphis lataniae Boisd. aphids. The essential oil from seeds was analyzed by GC-FID and GC-MS. The major compounds were safrole (38.8\%) and eucalyptol (21.7\%). Phenylpropanes $(51.7 \%)$ was the main group of compounds and oxygenated monoterpenes represented $28.8 \%$ of the total oil. The essential oil has shown no inhibition of acetylcholinesterase (AChE) in the tested concentrations. However, potential antioxidant activities were evaluated by different methods [DPPH: LD $_{50}=(27.8 \pm 1.0)$ $\mu \mathrm{g} / . \mathrm{mL}$; ABTS: $(977.3 \pm 25.2) \mu \mathrm{M}$ TEs/g (Trolox Equivalents); FRAP: $(548.2 \pm 29.0) \mu \mathrm{M} \mathrm{Fe}(\mathrm{II}) / \mathrm{g}]$. A significant larvicidal potential for $24 \mathrm{~h}$ of exposure was observed with $\mathrm{LD}_{50}=98.9 \mu \mathrm{g} / \mathrm{mL}$, being an indicative that the larval mortality may occur by ingestion or contact due to the no inhibition against AChE. Volatile phase effects were evaluated against $T$. urticae Koch. and $C$. lataniae Boisd. and $\mathrm{LD}_{50}$ were found about 30.8 and $13.5 \mu \mathrm{g} / \mathrm{mL}$, respectively. These results are consistent with an octopaminergic effect, since some phenylpropanoids (such as Safrole, identified as the major compound in this work) can block octopamine, a multi-functional, naturally occurring biogenic amine. Then, this study clearly illustrated the efficacy of the investigated seeds, which encourages the development of a new potential natural controlling agent against these common pests due to the abundance of these seeds in the Amazon region and to the high essential oil yield.
\end{abstract}

Keywords: Puxuri; Licaria puchury-major, bioassay; safrole .C 2018 ACG Publications. All rights reserved.

\section{Introduction}

Essential oils have been reported as efficient natural pesticides, without human hazards [1,2]. The pesticide effect of the Licaria puchury-major (Mart.) Kosterm. (Lauraceae) essential oil was evaluated in this work against three most common pests in tropical countries, which are currently causing severe damages in human health and agriculture: Aedes aegypti Linn. larvae, Tetranychus urticae Koch. mites and Cerataphis lataniae Boisd. aphids. Mosquito-transmitted diseases continue to be

*Corresponding author: E-Mail: sanches.ufam@gmail.com; Phone:+5592-984167887 
one of the leading causes of human death worldwide, and Aedes aegypti Linn., the yellow fever mosquito, has been widely distributed in tropical zones. Mosquito larvae control is a successful way of reducing mosquito densities [3]. Furthermore, the two-spotted spider mite, Tetranychus urticae Koch., is an important pest of agriculture, and many food crops or ornamental plants might be subject to their attack, resulting in its premature drying [4]. Finally, the palm aphid, Cerataphis lataniae Boisd., is a local pest of açaí (Euterpe oleracea Martus and E. precatoria Martus) palm's that may cause death of young plants or early fall of flowers and fruits [5]. In Amazon region, the control of this aphid has been nowadays based on its hand removal.

Studies reporting the larvicidal, acaricide and insecticidal bioactivities of the L. puchury-major essential oil have not been reported, to our knowledge, in scientific literature. Puxuri, puchury or pixuri [6] is native from Amazon and has been often used in the Brazilian northern folk medicine. Their aromatic seeds are resistant to decomposition due to its antimicrobial constituents and hardness shell [7]. A tea prepared with a powdered seed (known as "abafado") is used to treat stomach and intestinal diseases, as well as to treat insomnia and irritability [8]. Few studies reporting this species have been found in scientific literature, and they basically report its chemical composition [6-12]. The first chemical report of L. puchury-major [13] suggests a large amount of safrole. Previous work [9] has reported $36 \%$ and $11 \%$ of safrole and eugenol, respectively, in the essential oil from seeds. These same compounds were also found in the essential oils from leaves, branches and trunk-woods [11,12]. Previous work [10] has reported $58.4 \%$ of safrole as the major compound. Furthermore, this essential oil reduced motor activity and anesthetized mice [6]. To date, the more recent study concerning this species has reported the use of ethanol extract from seeds to inhibit cell proliferation in human leukemia cell line [14].

The evaluation of essential oils as alternative controlling agent may lead to the discovery of new natural products for pest control. For this reason, the present work aims to assess the potential of the $L$. puchury-major essential oil against the A. aegypti Linn., T. urticae Koch. and C. lataniae Boisd. The evaluation of acetylcholinesterase (AChE) inhibitory and antioxidant activities of some Lauraceae species have been extensively investigated $[15,16]$. However, few studies have described the antioxidant activity of essential oils from Licaria species, as well as the evaluation of acetylcholinesterase (AChE) inhibitory activity in order to correlate these results with the lethal dosage obtained in the performed bioassays. These results would be useful for the development of a natural agent for control based on this plant due to the abundance of these seeds in the Amazon region and to the high essential oil yield.

\section{Materials and Methods}

\subsection{Materials}

2,2-Diphenyl-1-picrylhydrazyl (DPPH), 2-(3,4-dihydroxyphenyl)-3,5,7-trihydroxy-4H-1benzopyran-4-on (quercetin), 2,2'-azino-bis(3-ethylbenzthiazoline-6-sulphonic acid) (ABTS), potassium persulfate $\left(\mathrm{K}_{2} \mathrm{~S}_{2} \mathrm{O}_{8}\right)$, 6-hydroxy-2,5,7,8-tetramethylchroman-2-carboxylic acid (Trolox), 2,4,6-tris(2pyridyl)-s-triazine (TPTZ), iron (III) chloride hexahydrate $\left(\mathrm{FeCl}_{3} \cdot 6 \mathrm{H}_{2} \mathrm{O}\right)$, ferrous sulphate $\left(\mathrm{FeSO}_{4}\right)$, acetylcholine idodete (AChI), acetylcholinesterase from Electrophorus electricus (electric eel), neostigmin bromide, sodium phosphate buffer and 5,5'-dithiobis(2-nitro-benzoic acid) (DTNB) were purchased from Sigma-Aldrich ${ }^{\circledR}$ and dimethyl sulfoxide (DMSO) were purchased from Tedia Hight Purity Solvents ${ }^{\circledR}$.

\subsection{Plant material and Essential Oil Extraction}

Seeds of L. puchury-major were collected in Belém/PA - Brazil and dried in controlled humidity at $30{ }^{\circ} \mathrm{C}$ until reach constant weight. The botanical identification was carried out at the Federal University of Amazonas (UFAM). Then, $150 \mathrm{~g}$ of powdered seeds were subjected to a Clevenger-type apparatus for $3 \mathrm{~h}$ at $100{ }^{\circ} \mathrm{C}$. The essential oil was treated using anhydrous sodium sulphate and stored at 
$-18{ }^{\circ} \mathrm{C}$. Essential oil yield was obtained by the ratio between the extracted oil volume to the plant material mass.

\subsection{Oil Characterization}

The essential oil relative density was estimated at $20{ }^{\circ} \mathrm{C}$. Two washed, dried capillary tubes were filled with distilled water $\left(m_{1}\right)$ or essential oil $\left(m_{2}\right)$ and weighed. Another capillary tube remained unfilled $(m)$ to obtain the weight difference of the full and empty capillary tubes. The density value was obtained according to the equation $\left[\mathrm{d}=\left(m_{2}-m_{1}\right) /\left(m_{1}-m\right)\right]$ and converted using the water density table [17]. DR-A1.

Raw essential oil's refraction index was estimated at $20{ }^{\circ} \mathrm{C}$ using an ABBE refractometer model

Thermogravimetric analysis was carried out using sample mass of $11.1080 \mathrm{mg}$ in a SDT Q600 (TA Instruments - USA). The experiment was carried out under $\mathrm{N}_{2}$ atmosphere $\left(100 \mathrm{~mL} \cdot \mathrm{min}^{-1}\right)$ with heating rate of $10{ }^{\circ} \mathrm{C} \cdot \mathrm{min}^{-1}$ from 30 to $300^{\circ} \mathrm{C}$.

Quantitative chromatographic analysis was carried out using a Shimadzu ${ }^{\mathrm{TM}}$ GC2010-FID instrument equipped with a FID detector and a DB-5 $(30 \mathrm{~m} \times 0.25 \mathrm{~mm}$, film thickness $0.25 \mu \mathrm{m}$ film thickness) fused silica capillary column. Injector and detector temperatures were $250{ }^{\circ} \mathrm{C}$ and $290{ }^{\circ} \mathrm{C}$, respectively; helium was used as carrier gas $\left(1.0 \mathrm{~mL} \cdot \mathrm{min}^{-1}\right)$; temperature column was from $60{ }^{\circ} \mathrm{C}$ to 250 ${ }^{\circ} \mathrm{C}$ with a rate of $3{ }^{\circ} \mathrm{C} \cdot \mathrm{min}^{-1}$. Split ratio $1: 10$ and $1.0 \mu \mathrm{L}$ of hexane solution. Qualitative chromatographic analysis was performed using a Shimadzu ${ }^{\mathrm{TM}}$ GCMS-QP2010 instrument and the same column used in the GC-FID analysis. The operating conditions were same as that of GC-FID, whose ionization energy and mass range were $70 \mathrm{eV}$ and 32 to $420 \mathrm{Da}$.

The identification of isolated compounds was established from their GC retention indices using a $_{6}-\mathrm{C}_{30} n$-alkanes homologous series, whose retention indices were calculated [18]. Moreover, essential oil compounds also were confirmed using published data [19], as well as through the Wiley 7.0 Registry of Mass Spectral Data [20], NIST [21] and Pherobase [22].

\section{4. $\mathrm{DPPH}$ and $A B T S^{++}$radical scavenging activity}

The essential oil radical scavenging ability was evaluated using the DPPH' radical [23] with slight modifications. $100 \mu \mathrm{M}$ of $\mathrm{DPPH}^{*}$ methanolic solution was prepared. $200 \mu \mathrm{L}$ of essential oils in five concentrations obtained by series dilution $(31.2$ to $1.9 \mu \mathrm{g} / \mathrm{mL})$ was added to $1800 \mu \mathrm{L}$ of DPPH methanolic solution. Quercetin was used as positive control $(25.0$ to $1.6 \mu \mathrm{g} / \mathrm{mL})$. The mixture was maintained in the dark at room temperature for $30 \mathrm{~min}$. The absorbance at $515 \mathrm{~nm}$ was measured using a UV-Visible Spectrophotometer (Thermo Scientific, Evolution 220). The inhibition percentage was obtained according to the equation: [100 - (absorbance/average absorbance of control) x 100]. The $\mathrm{LD}_{50}$ was defined as the amount of essential oil needed to inhibit the DPPH radical formation by $50 \%$. The bioassay was carried out in triplicate.

The essential oil radical scavenging capacity was evaluated using the ABTS method [24] with some modifications. The ABTS radical cation $\left(\mathrm{ABTS}^{\circ+}\right)$ solution was prepared using ABTS $(7 \mathrm{mM})$ and $\mathrm{K}_{2} \mathrm{~S}_{2} \mathrm{O}_{8}(140 \mathrm{mM})$ at room temperature for $16 \mathrm{~h}$. The absorbance of the resulting $\mathrm{ABTS}^{\circ+}$ solution was adjusted for $0.70 \pm 0.05$ at $734 \mathrm{~nm}$ via dilution using ethanol. $30 \mu \mathrm{L}$ of the resulting sample at different concentrations (from 62.5 to $1.9 \mu \mathrm{g} / \mathrm{mL}$ ) was diluted in $3000 \mu \mathrm{L}$ of the $\mathrm{ABTS}^{\circ+}$ solution. After $6 \mathrm{~min}$, the mixture absorbance was measured at $734 \mathrm{~nm}$ using a UV-Visible Spectrophotometer (Thermo Scientific, Evolution 220). Trolox was used for the calibration curve (100 a $2000 \mu \mathrm{M})$. The results were expressed as $\mu \mathrm{M}$ of Trolox Equivalent Antioxidant Capacity (TEAC) by grams of essential oil. 


\subsection{Ferric Reducing Antioxidant Power (FRAP)}

The FRAP test [25] was employed to evaluate the total antioxidant capacity of the essential oil. The FRAP reagent was freshly prepared adding acetate buffer $\left(0.3 \mathrm{~mol} \cdot \mathrm{L}^{-1}, \mathrm{pH}=3.6\right)$, TPTZ solution $(10 \mathrm{mM})$ and $\mathrm{FeCl}_{3} \cdot 6 \mathrm{H}_{2} \mathrm{O}(20 \mathrm{mM})$ in proportion 10:1:1. A sample aliquot $\left(90 \mu \mathrm{L}, 250 \mu \mathrm{g} \cdot \mathrm{mL}^{-1}\right)$ or positive control $\left(125 \mu \mathrm{g} . \mathrm{mL}^{-1}\right)$ was mixed with $270 \mu \mathrm{L}$ of ultrapure water and added to $2700 \mu \mathrm{L}$ of the FRAP reagent. After incubated for $30 \mathrm{~min}$ at $37{ }^{\circ} \mathrm{C}$, the absorbance was measured at $595 \mathrm{~nm}$ using a UV-Visible Spectrophotometer (Thermo Scientific, Evolution 220). The results was determined by the corresponding regression equation of ferrous sulphate $(250-2000 \mu \mathrm{M})$ and expressed in $\mathrm{Fe}(\mathrm{II})(\mu \mathrm{M}) \cdot \mathrm{g}^{-1}$ of essential oil. The assay was performed in triplicate. Quercetin was used as the positive control.

\subsection{Evaluation of Acetylcholinesterase (AChE) Inhibitory Activity}

AChE inhibitory activity of the essential oil was performed based on the method described previously [26] with some modifications. Solutions prepared with $20 \mu \mathrm{L}$ of sample $(500.0-7.8 \mu \mathrm{g} / \mathrm{mL})$, $80 \mu \mathrm{L}$ of phosphate buffer $(100 \mathrm{mM}), 40 \mu \mathrm{L}$ of dithiobisnitrobenzoic acid (DTNB, $2.5 \mathrm{mM})$, and $20 \mu \mathrm{L}$ of AChE $(1.0 \mathrm{U} / \mathrm{mL})$ were added to each microplate well at $37^{\circ} \mathrm{C}$ for $10 \mathrm{~min}$. Then, $40 \mu \mathrm{L}$ of acetylcholine iodide (AtCHI, $10 \mathrm{mM}$ ) was added and incubated again in the same conditions. $60 \mu \mathrm{L}$ of sodium dodecylsulphate (SDS, 1\%) was added as reaction terminator. The mixture absorbance was measured at $405 \mathrm{~nm}$. The percentage inhibition of AChE activity was calculated by [Inhibition (\%) = $\left.\left(A_{2}-\left(A_{1}-A_{3}\right) \times 100\right) / A_{2}\right]$, where $A_{1}$ is the sample and enzyme absorbance, $A_{2}$ is the enzyme absorbance, and $\mathrm{A}_{3}$ is the tested sample absorbance. The $\mathrm{LD}_{50}$ was obtained by curves of each inhibitor toward AChE. The bioassay was carried out in duplicate. Galantamine was used as standard from 25.0 to $1.6 \mu \mathrm{g} / \mathrm{mL}$.

\subsection{Statistical analysis}

The Kolmogorov-Smirnov test [27] was performed to evaluate the data distribution. Multiple data comparison was carried out based on the Tukey test [28]. Pearson correlation coefficients were obtained with $p<0.05$ and performed using the Minitab ${ }^{\text {TM }} 13.0$ software.

\subsection{Bioassays of Oil Solution}

Bioassays were conducted to test the $L$. puchury-major essential oil against $A$. aegypti Linn. larvae based on previous work [29] with some modifications. All bioassays were performed at $26 \pm 2{ }^{\circ} \mathrm{C}$ and $80 \% \mathrm{RH}$ in a photoperiod regimen of 12:12 h. Essential oil/dimethyl sulfoxide (DMSO) solutions were prepared at 500, 250, 100, 50 and $25 \mathrm{ppm} .500$ larvae at $3^{\text {rd }}$ instar were divided in 5 groups for each tested concentration. DMSO and temephos $(0.12 \mu \mathrm{g} / \mathrm{mL})$ were used as negative and positive control, respectively. This bioassay was carried out in quintuplicate and the larvicidal activity was estimated by the larvae mortality after $24 \mathrm{~h}, 48 \mathrm{~h}$ and $72 \mathrm{~h}$ of exposure. Data were analyzed in POLO $\mathrm{PC}{ }^{\circledR}$ program [30] for calculations of the $\mathrm{LD}_{50}$ (Lethal Concentration that kills $50 \%$ of the exposed larvae), $\mathrm{LD}_{90}$ (Lethal Concentration that kills $90 \%$ of the exposed larvae), LCL (Lower Confidence Limit) and UCL (Upper Confidence Limit) with fiducially limits of 95\%.

Evaluation of the acaricide and insecticidal potential of the essential oil was based on previous works [31,32]. Glass Petri plates $(90 \mathrm{~mm} \times 20 \mathrm{~mm} ; 130 \mathrm{~mL})$ were used for the evaluation of the essential oil's volatile phase effect. T. urticae Koch. and C. lataniae Boisd. were obtained, respectively, from stock colonies of papaya leaves (Carica papaya L.) and açaí palm (Euterpe oleracea Martus) without any pesticide exposure. Dorsal side leaves were placed on filter paper saturated with $1 \%$ sodium hypochlorite. Ten adults (mite or aphid) were transferred from stock using a soft paintbrush and allowed to settle before exposure. The tested oils were applied on filter paper disks at the inner surface of the Petri dish lid. Each concentration $(10 \mu \mathrm{L})$ of essential oil/dimethyl sulfoxide (DMSO) solution (1.0, $0.50,0.25,0.10,0.062$ and $0.031 \%$ ) was added on filter paper disk placed at the inner surface of the 
Petri dish lid. Plates were sealed. These bioassays were carried out in triplicate. DMSO and thymol (3.0 $\mu \mathrm{g} \cdot \mathrm{mL}^{-1}$ ) were used as negative and positive control, respectively. Mortality was evaluated after $24 \mathrm{~h}, 48$ $\mathrm{h}$ and $72 \mathrm{~h}$ of exposition. Mites or aphids were considered dead if they did not move when prodded with a fine paintbrush. The mortality data were subjected to the PROBIT analysis [33] for calculations of the $\mathrm{LD}_{50}, \mathrm{LD}_{90}, \mathrm{LCL}$ and UCL with fiducially limits of $95 \%$.

\section{Results and Discussion}

\subsection{Oil Characterization}

The extraction time has influenced the essential oil yield. The optimum extraction time was $3 \mathrm{~h}$. The essential oil yield was found around 5.5\% (w/v). Previous work [34] has reported that Lauraceae family plants presents essential oil yield higher than $1 \%$. The essential oil density was found to be 0.24 $\mathrm{g} / \mathrm{mL}$ and the estimated refraction index was 1.50 .

Simultaneous TG/dTG curves of the raw essential oil are shown in Figure 1.

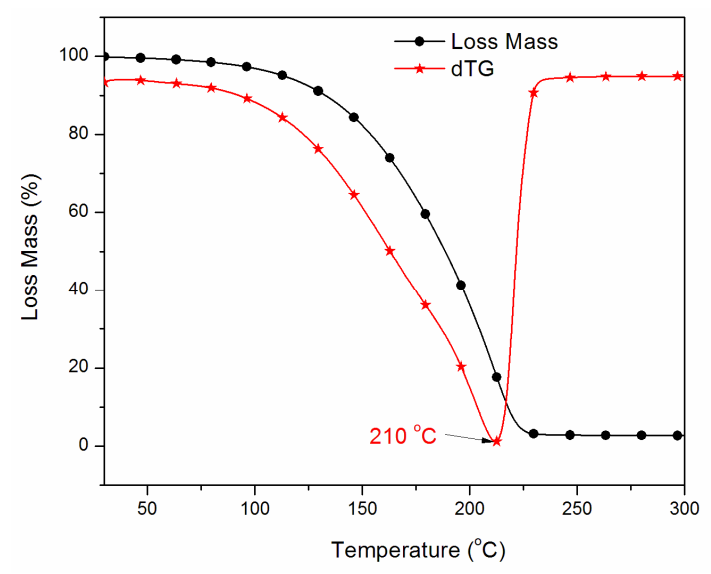

Figure 1. TG/dTG curves of the raw essential oil.

The essential oil remains stable up to $\sim 100{ }^{\circ} \mathrm{C}$, allowing the environmental exposure as a natural pesticide in tropical and subtropical countries due to its high thermal stability. In sequence, one stage related to loss mass/oil decomposition was observed from $\sim 100{ }^{\circ} \mathrm{C}$ to $210^{\circ} \mathrm{C}$. Above $210{ }^{\circ} \mathrm{C}$ there are no further decomposition stages.

Chemical analyses of the L. puchury-major essential oil are given in Table 1. The identified compounds were grouped based on its functional groups. Twenty compounds were identified, representing $98.4 \%$ of the raw essential. Based on CG-FID and GC-MS characterizations, Safrole (38.8\%) and Eucalyptol (21.7\%) were recorded as the most abundant compounds, totalizing $60.5 \%$.

As shown in Table 1, phenylpropanoids and oxygenated monoterpenes represent the main group ( 51.7 and $28.8 \%$, respectively) of the raw essential oil. Non-oxygenated monoterpenes represent $17.5 \%$, following by non-oxygenated sesquiterpenes $(0.5 \%)$, with just one compound (E-Caryophyllene). Oxygenated sesquiterpenes have not been found.

Lauraceae species from Amazon region are described as having large amount of Safrole in their aerial parts [34,35]. Besides the insecticidal, microbial and bactericidal activities of Safrole or other plants presenting large amount of this compound [36,37], these species could become an alternative to obtain this phenylpropene. On the other hand, it has been observed that some phenylpropene derivatives present important pharmacological effects in the central nervous system [38]. 
Table 1. Essential oil composition from the seeds of L. puchury-major.

\begin{tabular}{lcr}
\hline \multicolumn{1}{c}{ Compounds } & ${ }^{\prime} \mathbf{R I}_{\text {cal }}$ & Percentage \\
\hline$\alpha$-thujene & 924 & 0.18 \\
$\alpha$-pinene & 932 & 2.01 \\
sabinene & 969 & 3.95 \\
$\beta$-pinene & 974 & 1.47 \\
myrcene & 988 & 0.83 \\
$\alpha$-terpinene & 1014 & 0.17 \\
$o$-cymene & 1022 & 0.16 \\
limonene & 1024 & 8.27 \\
eucalyptol (1,8-cineole) & 1026 & 21.68 \\
$\gamma$-terpinene & 1054 & 0.33 \\
$Z$-sabinene hydrate & 1065 & 0.17 \\
terpinolene & 1086 & 0.09 \\
$\delta$-terpineol & 1162 & 0.32 \\
terpinen-4-ol & 1174 & 0.77 \\
$\alpha$-terpineol & 1186 & 5.82 \\
safrole & 1285 & 38.83 \\
eugenol & 1356 & 6.15 \\
methyl eugenol & 1403 & 6.56 \\
$E$-caryophyllene & 1417 & 0.47 \\
elemicin & 1555 & 0.16 \\
\hline Total (\%) & & 98.4 \\
\hline Non-oxygenated Monoterpenes (\%) & & 17.5 \\
Oxygenated Monoterpenes (\%) $(\%)$ & & 28.8 \\
Non-oxygenated Sesquiterpenes $(\%)$ & & 51.7 \\
Oxygenated Sesquiterpenes (\%) & & \\
Phenylpropanes (\%) & & \\
\hline$*$ R & & \\
\hline
\end{tabular}

\subsection{Antioxidant and AChE inhibitory activities}

According to Table 2, the L. puchury-major essential oil has showed sequestration capacity of $\mathrm{DPPH}^{\circ}$ and $\mathrm{ABTS}^{++}$, besides iron reducing capacity.

Table 2. Antioxidant and enzymatic activities of the L. puchury-major essential oil.

\begin{tabular}{ccccc}
\hline Sample/Standard & $\begin{array}{c}\text { DPPH }^{*} \\
\text { IC }_{\mathbf{5 0}} \pm \text { SD }\end{array}$ & $\begin{array}{c}\text { ABTS }^{*+} \\
\text { TEs }^{*} \text { SD }\end{array}$ & $\begin{array}{c}\text { FRAP } \\
\text { Eq. Fe(II) } \pm \text { SE }\end{array}$ & $\begin{array}{c}\text { AChE } \\
\text { GalanE }\end{array}$ \\
\hline Essential Oil & $27.83 \pm 0.99$ & $977.33 \pm 25.17$ & $548.20 \pm 29.00$ & na \\
Quercetin & $12.45 \pm 0.10$ & - & $1984.53 \pm 89.07$ & - \\
\hline
\end{tabular}

$\mathrm{IC}_{50}$ : expressed in $\mu \mathrm{g} / \mathrm{mL}$; ABTS: expressed in $\mu \mathrm{M} \mathrm{TEs} / \mathrm{g}$ (Trolox Equivalents); FRAP expressed in $\mu \mathrm{M}$ Eq Fe(II)/g; GalanE: Galantamine Equivalents; SD: Standard Deviation; na: not active. 
The antioxidant activity in $\mathrm{DPPH}^{*}$ and $\mathrm{ABTS}^{\circ+}$ assays reflects the hydrogen donating ability of a given compound. The L. puchury-major essential oil has shown $\mathrm{LD}_{50}=(27.8 \pm 1.0) \mu \mathrm{g} / \mathrm{mL}$, and $44.6 \%$ of activity rate when compared to Quercetin. The $\mathrm{ABTS}^{\cdot+}$ radical scavenging activity was $(977.3 \pm 25.2)$ $\mu \mathrm{M}$ TEs/g of essential oil. The FRAP assay was performed to evaluate the reduction of $\mathrm{Fe}^{3+}$ to $\mathrm{Fe}^{2+}$ in the presence of antioxidants. The essential oil showed (548.2 \pm 29.0$) \mu \mathrm{M} \mathrm{Fe}(\mathrm{II}) / \mathrm{g}$, and $44.3 \%$ of activity rate when compared to Quercetin in the tested concentrations. The calibration curves for the equivalence calculations for Trolox and ferrous sulfate are shown in Figure 2. Our results may be explained by the presence of the phenylpropanes, Safrole (38.8\%) and Eugenol (6.1\%), besides the oxygenated monoterpenes, 1,8-Cineole (21.7\%), which present important antioxidant properties [39,40].
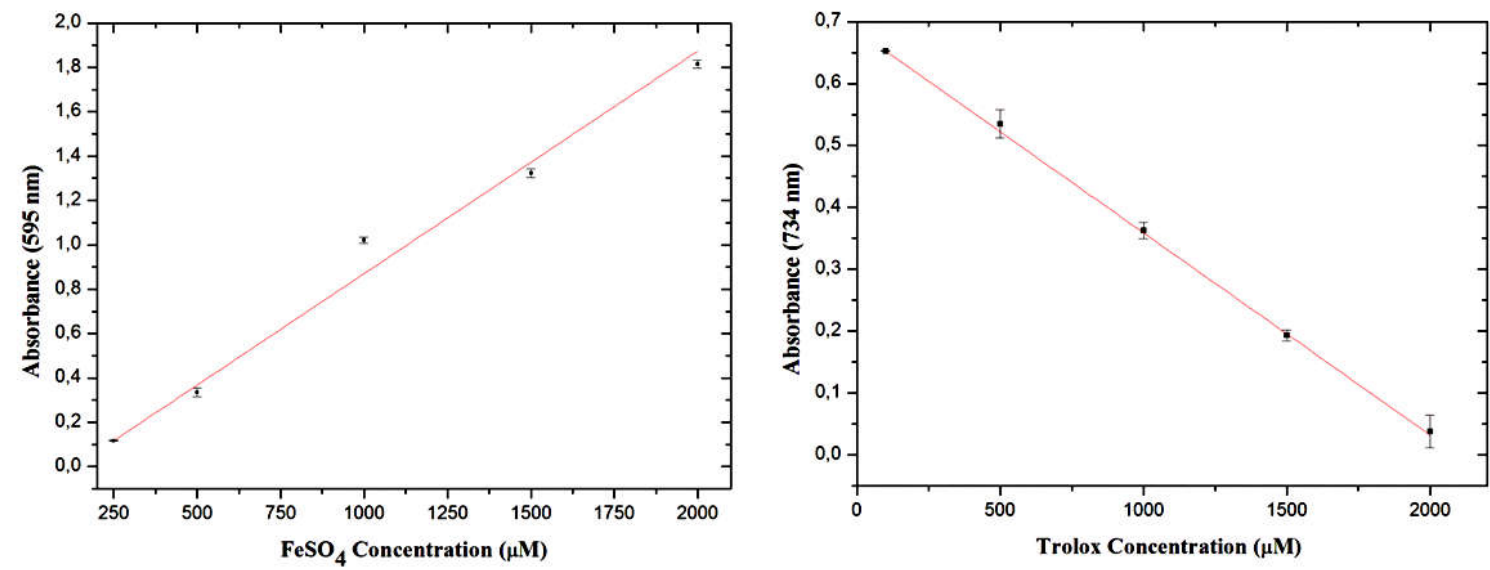

Figure 2. Calibration curves for the equivalence calculations for Trolox and ferrous sulfate.

No inhibition of acetylcholinesterase (AChE) was observed in the tested concentrations. Essential oils of Lauraceae family are rich in Safrole (54-59\%), which has presented AChE inhibitory activity above $1000 \mu \mathrm{g} / \mathrm{mL}[41]$.

\subsection{Bioassays}

Organophosphorate temephos are the most commonly employed larvicide for Aedes and Anopheles control. However, its toxicity has been increasingly reported besides the insecticide resistance of arthropods [42,43]. Most plant-derived compounds have shown great potential as natural pesticide, presenting low toxicity to non-target organisms, as well as to the environment. For this reason, the susceptibility of many species of mosquito larvae to plant products has been extensively studied $[44,45]$.

Table 3. $\mathrm{LD}_{50}$ and $\mathrm{LD}_{90}$ values of the L. puchury-major essential oil against $A$. aegypti Linn.

\begin{tabular}{cccccc}
\hline Exposure & $\mathbf{L D}_{\mathbf{5 0}} \pm \mathbf{S D}$ & $\mathbf{( L C L}-\mathbf{U C L})$ & $\mathbf{L D}_{\mathbf{9 0}} \pm \mathbf{S D}$ & $\mathbf{( L C L}-\mathbf{U C L})$ & Regression Equation \\
\hline $24 \mathrm{~h}$ & $98.9 \pm 0.6$ & $67.84-141.41$ & $228.8 \pm 0.6$ & $141.41-156.23$ & $Y=(-0.23+0.05)+0.48 X$ \\
$48 \mathrm{~h}$ & $79.1 \pm 0.4$ & $52.76-108.23$ & $200.7 \pm 0.4$ & $140.31-431.64$ & $Y=(-0.23+0.05)+0.47 X$ \\
$72 \mathrm{~h}$ & $59.8 \pm 0.3$ & $42.57-78.06$ & $167.6 \pm 0.3$ & $122.10-293.43$ & $Y=(-0.18+0.05)+0.35 X$ \\
\hline
\end{tabular}

$L D_{50}$ : Lethal Dosage that kills $50 \%$ of the exposed larvae, expressed in $\mu \mathrm{g} \cdot \mathrm{mL}^{-1} ; L D_{90}$ : Lethal Dosage that kills $90 \%$ of the exposed larvae, expressed in $\mu \mathrm{g} . \mathrm{mL}^{-1} ; Y:$ mortality rate (significant at $P<0.05$ level); $X$ : concentration (significant at $P<0.05$ level); $S D$ : Standard Deviation; $L C L$ : Lower Confidence Limit; $U C L$ : Upper Confidence Limit. Negative control: DMSO; Positive control: Temephos $\left(0.12 \mu \mathrm{g} \cdot \mathrm{mL}^{-1}\right)$.

Interest in the control of $A$. aegypti larvae lies in the fact that they represent serious public health problems in many developing countries. Plant extracts of the Lauraceae family have been reported as effective natural pesticides against $3^{\text {th }}$ and $4^{\text {th }}$ instars larvae stages [46]. Larvicidal activity of L. puchury-major essential oil was not reported earlier. Our work shows that the essential oil from its 
seeds may be an efficient alternative to $A$. aegypti larvae control. After exposure to the essential oils, the knock-down effect was observed [35]. A significant larvicidal potential for $24 \mathrm{~h}$ of exposure was observed. The $\mathrm{LD}_{50}$ and $\mathrm{LD}_{90}$ values are shown in Table 3.

The $\mathrm{LD}_{50}$ and $\mathrm{LD}_{90}$ were found to be 98.9 and $228.8 \mu \mathrm{g} / \mathrm{mL}$, respectively, for $24 \mathrm{~h}$ of exposure. For $48 \mathrm{~h}$ of exposure, the $\mathrm{LD}_{50}$ and $\mathrm{LD}_{90}$ were 79.1 and $200.7 \mu \mathrm{g} / \mathrm{mL}$, respectively. Finally, for $72 \mathrm{~h}$ of exposure, concentrations of 59.8 and 167.6 were observed, respectively, for $\mathrm{LD}_{50}$ and $\mathrm{LD}_{90}$. The $\mathrm{LD}_{90}$ provides information about the concentration that causes the maximum reduction of mosquito generation. Unfortunately, this data has not always been reported in scientific literature. Our results have shown that this essential oil may be applied as a natural larvicidal against the A. aegypti.

Acaricide and insecticidal activities of L. puchury-major essential oil were not reported earlier. Essential oils commonly contain compounds that present particular roles [47]. Such plant products have shown efficient insect toxicity in vapour phase, being reported as more toxic to the microorganisms than the contact form [32]. The total mortality of T. urticae Koch. and C. lataniae Boisd. was observed at $500 \mathrm{ppm}$ and $250 \mathrm{ppm}$ for $24 \mathrm{~h}$ of exposure. The $\mathrm{LD}_{50}$ and $\mathrm{LD}_{90}$ were, respectively, 30.8 and 87.1 $\mu \mathrm{g} / \mathrm{mL}$.

Although literature presents a range of similar studies showing the acaricide activity of essential oils, there is a deficit concerning the T. urticae Koch. Among the few published works [48], the sublethal effects of the Cinnamomum zeylanicum essential oil has shown $\mathrm{LD}_{50}=23.4 \mu \mathrm{L} / \mathrm{L}$. Similarly, the toxicity of two insecticides against moveable stages of immature T. urticae Koch. has been reported [49] after $24 \mathrm{~h}$ of exposure, with $\mathrm{LD}_{90}$ of 90.3 and $103.9 \mu \mathrm{g} / \mathrm{mL}$ for, respectively, vermitec ${ }^{\circledR}$ and spinetoram.

The insecticidal bioassay against the $C$. lataniae Boisd. has showed efficient activity. Studies reporting the use of essential oils against this aphid have not been found in scientific literature. After 24 $\mathrm{h}$ of exposure, $91 \%$ of mortality was observed. The $\mathrm{LD}_{50}$ and $\mathrm{LD}_{90}$ were, respectively, 13.5 and 72.8 $\mu \mathrm{g} / \mathrm{mL}$, as shown in Table 4 .

A recent study [50] have reported the $\mathrm{LD}_{50}$ against $A$. craccivora using plants collected from mid hills of western Himalayas in the range of 55-60 ppm. These results are comparable to chemical insecticides, which have demonstrated $\mathrm{LD}_{50}$ in the range of $25-51 \mathrm{ppm}$. Similarly, Lima et al., 2009 [35] have reported the lethal dosage of Piper hispidinervum essential oil and its effect on the comportment and/or mortality of the Spodoptera frugiperda. Safrole (82.0\%) was reported as the major compound and the $\mathrm{LD}_{50}$ was $18.2 \mathrm{mg} / \mathrm{mL}$ for $24 \mathrm{~h}$ of exposure.

Then, our results concerning the L. puchury-major essential oil presented efficient insecticidal activity against the two-spotted spider mite and the palm aphid, making the puxuri a great candidate for a new natural agent for these pest control.

Table 4. $\mathrm{LD}_{50}$ and $\mathrm{LD}_{90}$ values of the L. puchury-major essential oil against T. urticae Koch. and C. latanitae Boisd.

\begin{tabular}{|c|c|c|c|c|c|}
\hline Species & $\mathbf{L D}_{50} \pm \mathbf{S D}$ & (LCL-UCL) & $\mathbf{L D}_{90} \pm \mathrm{SD}$ & (LCL-UCL) & Regression Equation \\
\hline T. urticae Koch. & $30.8 \pm 0.3$ & $18.1-40.3$ & $87.1 \pm 0.3$ & $66.9-145.0$ & $Y=(4.22+0.05)+2.84 X$ \\
\hline C. lataniae Boisd. & $13.5 \pm 0.8$ & $1.4-25.7$ & $72.8 \pm 0.8$ & $47.4-139.6$ & $Y=(1.98+0.05)+1.75 X$ \\
\hline
\end{tabular}

Many essential oils have been shown bioactivities against insects or invertebrates. However, few studies provide their mode of action in individual species. It is unknown whether the activities of the essential oil mixtures are due to the individual compounds or to synergistic interactions between their constituents. Bioassays performed with some essential oils resulted in characteristic symptoms of neurotoxic mode of action. The knockdown effect observed in the present work is similar to those produced by organophosphates and carbamates. Some phenylpropanoids (such as Safrole, identified as the major compound in this work) can block octopamine [51], which plays an important role in invertebrate systems [52]. The acute and sub-lethal behavioral effects of essential oil compounds in 
invertebrates are consistent with an octopaminergic effect. The knockdown effect, toxicity and repellency of Safrole and other phenylpropanoids were reported in previous work [53]. Complementing these results, Eucalyptol (identified as the second major compound in this work) is also reported to has depressant effects on the central nervous system [54]. For this reason, these findings indicate that the route of action for the essential oil might be suggested via octopaminergic effect.

Furthermore, the L. puchury-major essential oil analysis showed two major compounds (Safrole and Eucalyptol) with confirmed bioactivities. For this reason, our results suggest this essential oil presented an efficient potential for use in the control of the yellow fever mosquito, the two-spottes spider mite and the palm aphid. In conclusion, this study clearly illustrated the efficacy of the investigated seeds, which encourages the development of a potential alternative as new natural pesticide. However, further studies will be conducted to evaluate the cost-efficacy of this essential oil on wide range of pests. Furthermore, the abundance of puxuri seeds in the Amazon region, as well as the large essential oil yield under hydrodistillation extraction makes this species a great candidate as an effective natural pesticide.

\section{Acknowledgments}

The authors thank Conselho Nacional de Desenvolvimento Científico e Tecnológico (CNPq, Processo $n^{\circ}$ 403496/2013-6 and 401508/2016-1), Financiamento de Estudos de Projetos e Programas (FINEP, 0245/08 and 0391/09), Fundação de Amparo à Pesquisa do Estado do Amazonas (FAPEAM, 022/13-FIXAM/AM) financial supports, Centro de Biotecnologia da Amazônia (CBA, Manaus/AM), Instituto Nacional de Pesquisa da Amazônia (INPA), as well as the Central Analítica/UFAM.

\section{ORCID}

Sidney G. Azevedo: 0000-0001-8742-4399

Josiana M. Mar: 0000-0003-4442-6874

Laiane S. da Silva: 0000-0001-7037-0275

Leandro P. França: 0000-0002-7190-2875

Marcos B. Machado: 0000-0002-8791-4803

Wanderli P. Tadei: 0000-0002-0612-3285

Jaqueline de A. Bezerra: 0000-0002-9168-9864

Amanda L. dos Santos: 0000-0002-1770-9214

Edgar A. Sanches: 0000-0002-1446-723X

\section{References}

[1] R. Srinivasan, D. Natarajan, M. S. Shivakumar, T. Vinuchakkaravarthy and V. Velmurugan (2015). Bioassay guided isolation of mosquito larvicidal compound from acetone leaf extract of Elaeagnusindica Servett Bull. and its in-silico study, Ind. Crop. Prod. 76, 394-401.

[2] D. Onstad, Z. Pan, M. Tang and J. L. Flexner (2014). Economics of long-term IPM for western corn rootworm, Ind. Crop. Prod. 64, 60-66.

[3] M. S. Fradin and J. F. Day (2002). Comparative efficacy of insect repellents against mosquitoes bites, $N$. Engl. J. Med. 347, 13-18.

[4] C. H. W. Flechtmann (1996). Rediscovery of Tetranychusabacae Baker \& Pritchard, additional description and notes on South American spider mites (acari, prostigmata, tetranychidae), Revta. Bras. Zool. 13, 569578.

[5] L. A. Souza and W. P. Lemos (2004). Prospecção de insetos associados ao açaizeiro (Euterpe oleraceae Mart.) em viveiro e proposições de controle, Rev. Ciênc. Agrar. 42, 231-241.

[6] E. A, Carlini, A. B. Oliveira and G. G. Oliveira (1983). Psychopharmacological effects of the essential oil fractions and of the hydrolate obtained from the seeds of Licaria puchury-major, J. Ethnopharmacol. 8, 225-236. 
[7] M. Himejima and I. Kubo (1992). Antimocrobial agents from Licaria puchury-major and their synergistic effect with polygodial, J. Nat. Prod. 55, 620-625.

[8] J. G. S. Maia, L. S. Ramos and A. I. Luz (1985). Estudo do óleo essencial do puxuri por cromatografia gás/espectrometria de massa (CG/EM), Acta Amaz. 15, 179-183.

[9] O. R. Gottlieb (1956). Estudo do óleo essencial da fava do puxuri, Bol. Inst. Quim. Agr. 43, 14-23.

[10] E. A. Sanches, G. Trovati and G. O. Chierice (2008). Chemical analysis of the essential oil extracted from the seeds of Licaria puchury-major, J. Essent. Oil. Res. 20, 191-192.

[11] A. P. Seabra, E. C. Guimarães and W. B. Mors (1967). Estudo do óleo essencial de "puxuri" por cromatografia gás-líquido, An. Assoc. Bras. Quim. 26, 73-78.

[12] M. L. Silva, J. G. S. Maia, C. M. A. Rezende and O. R. Gotlieb (1973). Arylpropanoide from Licaria puchury-major, Phytochemistry 12, 471-472.

[13] E. Gildemeister and F. Hoffmann (1916). The volatile oils. John Wiley and sons, 487-488.

[14] T. Uchiyama, K. Tabata, S. Nomura, Y. Kaneko, Y. Fujimoto and T. Suzuki (2009). Induction of Apoptosis in Human Leukemia Cell (Jurkat) by Neolignans Isolated from Seeds of Licaria puchury-major, Biol. Pharm. Bull. 32, 1749-1753.

[15] A. Boulila, I. E. Hassen, L. Haouri, F. Mejri, I. B. Amor, H. Casabianca and K. Hosni (2015). Enzymeassisted extraction of bioactive compounds from bay leaves (Laurus nobilis L.), Ind. Crop. Prod. 74, 485493.

[16] J. K. da Silva, R. C. da Trindade, J. G. Maia and W. N. Setger (2016). Chemical Composition, Antioxidant, and Antimicrobial Activities of Essential Oils of Endlicheria arenosa (Lauraceae) from the Amazon, Nat. Prod. Commun., 11, $695-698$.

[17] R. H. Perry, D. W. Green and J. O. Maloney (1997). Densities of pure substances. In: Perry's Chemical Engineers' Handbook, 7.ed., New York: McGraw-Hill.

[18] H. Van den Dool and P. D. Kratz (1963) A generalization of the retention index system including linear temperature programmed gas-liquid partition chromatography, J. Chromatogr. 11, 463-471.

[19] R. P. Adams (2009). Identification of essential oil components by gas chromatography/mass spectrometry. 4.ed. Illinois: Allured Publishing Corporation.

[20] F. W. Mckafferty, D. B. Stauffer and S. Y. Loh (1991). Comparative evaluations of mass spectral databases, J. Am. Soc. Mass Spectr. 2, 438-440.

[21] NIST Standard Reference Data, 2016. http://webbook.nist.gov/chemistry.

[22] The Pherobase: Database of Pheromones and Semiochemicals. <http://www.pherobase.com>.

[23] P. Molyneux (2004). The use of the stable free radical diphenylpicryl- hydrazyl (DPPH) for estimating antioxidant activity, J. Sci. Technol. 26, 211-219.

[24] R. Re, N. Pellegrini, A. Proteggente, M. Yang and C. Rice-Evans (1999). Antioxidant activity applying an Improved ABTS Radical Cation Decolorization Assay, Free Radical Bio. Med. 26, 1231-1237.

[25] R. Pulido, L. Bravo and F. Saura-Calixto (2000). Antioxidant Activity of Dietary Polyphenols As Determined by a Modified Ferric Reducing/Antioxidant Power Assay, J. Agr. Food Chem. 48, 3396-3402.

[26] G. L. Ellman, K. D. Courtney, V. Andres Jr. and R. M. Featrrstone (1961). A new and rapid colorimetric determination of acetylcholinesterase activity, Biochem. Pharmacol. 7, 88-95.

[27] W. Daniel (1990). Applied Nonparametric Statistics. 2.ed. Boston: PWS-Kent Publishing Company, 319330 .

[28] J. Tukey (1949). Comparing Individual Means in the Analysis of Variance, Biometrics. 5, 99-114.

[29] H. T. Dulmage, J. A. Correa, G. Gallegos-Morales (1990). Bacterial control of mosquitoes and black flies. In: H. Barjac and D. J. Sutherland (Ed.). New Jersey: Rutgers University Press, 110p.

[30] J. R. Robertson, H. K. Preisler, R. M. Russel (2002). Polo Plus. Probit and logit analysis user's guide. Petaluna, CA: LeOra Software.

[31] I. Aslan, H. Ozbek, O. Çalmasur and F. Sahin (2004). Toxicity of essential oil vapours to two greenhouse pests, Tetranychus urticae Koch and Bemisiatabaci genn, Ind. Crop. Prod. 19, 167-173.

[32] E. M. Soylu, S. Soylu and S. Kurt (2006). Antimicrobial activities of the essential oils of various plants against tomato late blight disease agent Phytophthora infestans, Mycopathologia 161, 119-128.

[33] D. J. Finney (1971). Probit analysis. Third edition. Cambridge University Press, 333.

[34] J. M. Alcântara, K. K. L. Yamaguchi and V. F. J. Veiga (2010). Composição química de óleos essenciais de espécies de Aniba e Licaria e suas atividades antioxidante e antiagregante plaquetária, Quim. Nova. 33, 141-145.

[35] R. K. Lima, M. G. Cardoso, J. C. Moraes, B. A. Melo, V. G. Rodrigues and P. L. Guimarães (2009). Atividade inseticida do óleo essencial de pimenta longa (Piper hispidinervum C. DC.) sobre lagarta-docartucho do milho Spodoptera frugiperda (J. E. Smith, 1797) (Lepidoptera: Noctuidae), Acta Amaz. 39, 377-382. 
[36] S. A. Hhayyat and S. H. Al-Zahrani (2014). Thermal, photosynthesis and antibacterial studies of bioactive safrole derivative as precursor for natural flavor and fragrance, Arab. J. Chem. 7, 800-804.

[37] J. Dognini, E. K. Meneghetti, M. N. Teske, I. M. Begnini, R. A. Rebelo, E. M. Dalmarco, M. Verdi and A. L. Gasper (2012). Antibacterial activity of high safrole contain essential oils from Piper xylosteoides (Kunth) Steudel, J. Essent. Oil Res. 3, 241-244.

[38] A. B. Sell and E. A. Carlini 91976). Anesthetic action of methyleugenol and other eugenol derivatives, Pharmacology, 14, 367-377.

[39] M. E. Hidalgo, C. de La Rosa, H. Carrasco, W. Cardona, C. Gallardo and L. Espinoza (2009). Antioxidant capacity of eugenol derivatives, Quím. Nova 32, 467-1470.

[40] G. Singh, S. Maurya, M. P. de Lampasona and C. A. N. (2007). A comparison of chemical, antioxidant and antimicrobial studies of cinnamon leaf and bark volatile oils, oleoresins and their constituents, Food chem. Toxicol. 45, 1650-1661.

[41] W.M.N.H.W. Salleh, F. Ahmad and K. H. yen (2015). Antioxidant and Anticholinesterase Activities of essential oils of Cinnamomum griffithiiand C. macrocarpum, Nat. Prod. Commun. 10, 1465-1468.

[42] B. Pitasawat, D. Champakaew, W. Choochote, A. Jitpakdi, U. Chaithong, D. Kanjanapothi, E. Rattanachanpichai, P. Tippawangkosol, D. Riyong, B. Tuetun and D. Chaiyasit (2007). Aromatic plantderived essential oil: An alternative larvicide for mosquito control, Fitoterapia, 78, 205-210.

[43] A. E. Pinkney, P. C. McGowan, D. R. Murphy, T. P. Lowe, D. W. Sparling and W. H. Meredith (1999). Effects of temephos (abate registered 4E) on fiddler crabs (Uca pugnax and Uca minax) on a Delaware salt marsh, J. Am. Mosq. Control Assoc. 15, 321-329.

[44] A. Amer and H. Mehlhorn (2006). Larvicidal effects of various essential oils against Aedes, Anopheles, and Culex larvae (Diptera, Culicidae), Parasitol. Res. 99, 466-472.

[45] R. Pavela (2015). Essential oils for the development of eco-friendly mosquito larvicides: A review, Ind. Crop. Prod. 76, 174-187.

[46] R. C. Torres, A. G. Garbo, R. Z. M. L. Walde (2014). Larvicidal activity of Persea americana Mill. against Aedes aegypti, Asian Pac. J. Trop. Med. 7, S167-S170.

[47] F. Bakkali, S. Averbeck, D. Averbeck and M. Idaomar (2008). Biological effects of essential oils - a review, Food Chem. Toxicol. 46, 446-475.

[48] R. Rezaei, J. Karimi, H. Abbasipour and A. Askarianzadeh (2014). Sublethal effects of essential oil of Cinnamomum zeylanicum Blume on life expectancy $\left(e_{x}\right)$ and age-specific fertility $\left(m_{x}\right)$ of two-spotted spider mite, Tetranychus urticae Koch (Acari: Tetranychidae), Arch. Phytopathol. 47, 900-905.

[49] G. A. El Kady, H. M. El Sharabasy, M. F. Mahmoud and I. M. Bahgat (2007). Toxicity of Two Potential Bio-insecticides against moveable stages of Tetranychus urticae Koch, J. Appl. Sci. Res. 3, 1315-1319.

[50] D. K. Tewary, A. Bhardwaj and A. Shanker (2005). Pesticidal activities in five medicinal plants collected from mid hills of western Himalayas, Ind. Crop. Prod. 22, 21-247.

[51] E. Enan (2011). Inseticidal activity of oils: octopaminergic sites of action, Comp. Biochem. Physiol. 130, 325-337.

[52] R. S. Rattan (2010). Mechanism of action of inseticidal secondary metabolites of plant origin, Crop Protect. 29, 913-920.

[53] S. P. Ngoh, L. E. W. Choo, F. Y. Pang, Y. Huang, M. R. Kini, S.H. Ho (1998). Insecticidal and repellent properties of nine volatile constituents of essential oils against the American cockroach, Periplaneta americana (L.), J. Pestic. Sci. 58, 261-268.

[54] F. A. Santos and V. S. N. Rao (2000). Anti-inflammatory and antinociceptive effects of 1,8-cinole a terpenoid oxide present in many plant essential oils, Phytother. Res. 14, 240-244.

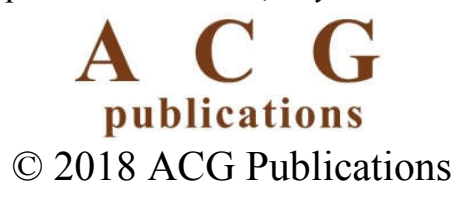

